\title{
PROBLEM WYSŁUCHANIA MODLITWY U KLEMENSA ALEKSANDRYJSKIEGO
}

Zagadnienie modlitwy zajmuje w pismach Klemensa Aleksandryjskiego stosunkowo wiele miejsca. Nie opracował on wprawdzie specjalnego traktatu na ten temat, jak to czynili późniejsi autorzy chrześcijańscy, lecz zgodnie ze swym założeniem często do niej nawiązywał przy omawianiu innych kwestil.

Klemensa interesuje przede wszystkim modlitwa doskonałego chrześcijanina czyli gnostyka, której istote stanowi o b c a w a n 1 e $z \quad B \circ g i$ e $\quad$ w m $i$ o ś $i^{1}$. Dla gnostyka nie jest ważne czy w danym momencie prosi o coś Boga czy dziękuje, lecz sam fakt obcowania, co Klemens określa słowem "homilia". Modlitwa prośby jest zatem jednym z rodzajów tegoz obcowania, rodząc się z konkretnej sytuacji, w jakiej znalazł się gnostyk; jest ona wyrazem wiary w Bożą dobroć i Opatrzność. Doskonały chrześcijanin przedstawiając Panu Bogu pewne potrzeby własne czy innych ludzi, nie traktuje modlitwy instrumentalnie. Nie jest tak, że głównym jej celem jest jakieś dobro, a środkiem do jego zdobycia - modlitwa, gdyź ma ona sens sama w sobie. Takie podejście do modlitwy czyli obcowania z Bogiem wypływa z dojrzałej agape ${ }^{2}$, jaka posiadał gnostyk w procesie doskonalenia się pod kierunkiem Boskiego Logosu ${ }^{3}$.

Gnostykowi obcującemu z Bogiem w miłości obce jest magiczne traktowanie modlitwy, wáaściwe religiom pogańskim, jak również wszelki automatyzm w tym wzglęizie. Słowa wypowiadane podczas modlitwy nie mają na celu wyiasié na Bogu udzielenia w sposób nadzwyczajny

1 F. Drączkowski, Znaczenie słów Klemensa Aleksandryjskiego "modlitwa jest rozmowaz z Bogiem" w ich kontekście bliźszym 1 dalszym, TST 8/1981/ 129-132, spec. 131-132.

2 F. Drączkowsk1, Kościół-agape, Lublin 1983, 84.

3 'Tamże, 146-158. 
jakichkolwiek darów, lecz racja ich wypowiadania jest przede wszystkim oddanie Bogu chwały. Gnostyk nie ocenia wartości modlitwy według jej praktycznej użyteczności, a jednocześnie ma świadomość, że jego modlitwy bywają zawsze wysłuchane 1 to niekiedy w sposób natychmiastowy ${ }^{4}$.

"Jak mianowicie Bóg potrafi wszystko, co zechce, tak samo gnostyk otrzyma wszystko, czego zaząda"5.

Powstaje tu cały szereg pytań: Jeżeli skuteczność modlitwy nie mierzy się jej zewnętrznym skutkiem, to jak można poznać, że została ona wysłuchana lub nie? Jeżeli ważne jest samo obcowanie z Bogiem, nie zaś przedmiot próśb, to skąd się bierze pewność, że "gnostyk otrzyma wszyștko, czego zażąda"? Na jakiej podstawie zapewnia Klemens o tak wysokiej wartości, a nawet skuteczności modlitwy gnostyka w jej dostrzegalnya wyiniarze? W czym upatruje Klemens istotę wysłuchania modlitwy? Niniejszy artykuł będzie próbą zrozumienia myśli Klemensa w tyin względzie oraz zarysowania przynajmniej szkicowych odpowiedzi na postawione pytania.

W swoich wypowiedziach na temat wysłuchania modlitwy Teolog aleksandryjski zwraca uwagę na samą postawę modlącego się, w tym przy. padku gnostyka. "Doszedł on do tak wysokiego stopnia śriętośc1, że jest juź raczej gotów, aby jego prośba nie uzyskała spełnienia" ${ }^{6}$, niz żeby uzyskać coś, co byłoby niezgodne z wolą Bożą. Jest to niewątpliwie postawa nieograniczonego zaufania do Bożej dobroci, wynikajaca z chęci trwania w nieprzerwanej przyjaźni z Bogiem. Przyjaźn tę gnostyk ceni bardziej niż jakiekolwiek dobra. Klemens mając na uwadze kierującą światem Bożą Opatrzność był zdania, że "użyczenie daru następuje nie ze względu na osobę proszącego, lecz ze względu na Boski plan zbawienia. W ten sposób tym, którzy istotnie są tego godni, prawdziwe dobra użyczane sa nawet wtedy, gdy nie prosza o nie" $7^{7}$. Swia. domość, że Bóg z góry przewidział, co komu potrzebne, nie przekreśla

4 Stromateis VII $44,5, \operatorname{GCS} 17,33$.

5 Stromateis VII 41, 4, GCS 17, 31. Posługuję się przekładem J. Pliszczyńskiej w rękopisie.

6 Stromateis VII 73,1 , GCS $17,52$.

7 Stromateis VII 73,4 , GCS 17,52 . 
jednak sensowności modlitwy błagalnej:

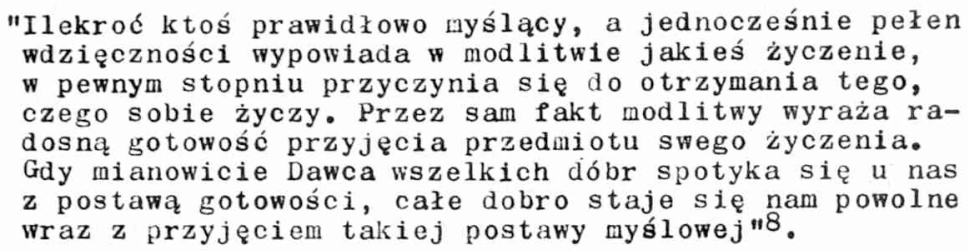

Autor dostrzega w tym pewną tajemnicę i nie podejmuje się wyjaśnić związku prośby z otrzymaniem darów w sposób nie pozostawiający żadnych wątpliwości, lecz stwierdza, że modlący się "w pewnym stopniu przyczynia się do otrzymania tego, czego sobie życzy", czyli że związek taki istnieje.

Na kartach swoich dzieł Klenens nie podaje warunków wysłuchania modlitwy w sensie ścisłym, lecz raczej wskazuje na to, co może przyczynić się do otrzymania przedmiotu prośby lub pragnienia. W jego wypowiedziach można odkryć dwa takie czynniki. Przedewszystkim człowiek, który chce otrzymać cokolwiek od Boga, musi być "prawidłowo myślący" ( $\varepsilon \cup j \pi \rho \propto \ell \rho \varepsilon \tau \circ \varsigma$ ) to znaczy, posiadający odpowiednią formację umysłową, podejmujący wszelkie decyzje w sposób przemyślany i rozważny. Formację taką daje oczywiście gnoza 9 . Człowiek bowiem, który nie ma odpowiedniej formacji, nie posiada dostatecznego poznania Boga i spraw nadprzyrodzonych, nie jest w stanie rozważnie czyli prawidłowo ocenić, czego naprawdę potrzebuje, ani też nie potrafi odpowiednto zwrócié się do Boga.

Drugım niezbędnym czynnikiem warunkującym lub wpływającym na przyjęcie 1 wysłuchanie modlitwy jest postawa dziękczynna. Ma ona

8 Stromateis VII $43,1-2, \operatorname{GCS} 17,32$.

9 F. Drączkowski, Qua paideia Clemens Alexandrinus imbutus appareat in animadvertenda Palsa gnosi, SACh 2/1980/61: "Summam cognitionem ethicae, quae a fide initium duxerat, Clemens Alexandrinus $g$ o $s$ i n nominat, quam assequendam conatur christianus perfectus, id est perfectus gnosticus. Verae autem gnosi coniuncta est a g a p e, quae, secundum nonnulla dicta Clementis, superat $\mathrm{g} n$ o $\mathrm{s}$ i n. Alits locis operum suorum Clemens ambas, id est g $n \circ s i n$ et a $g$ a $\mathrm{p} n$, aequales esse putare videtur". 
towarzyszyć modlącemu się, zanitu otrzyma to, o co prosi. Wdził̧czność wobec Boga nie powinna być czyuś wtórnym do otrzynania jakiegoś daru. Byłaby to bowiem postawa zbyt naturalistyczna, niegodna doskonałego chrześcijanina. Gnostyk nie mierzy swojej miłości ani wdzięczności wobec Boga drobiazgami dnia codziennego. Kocha Boga nie za jakąś konkretną przysługe, lecz po prostu dlatego, ze jest Bogiem. Nie dary są przedmiotem jego umiłowania, lecz sam Bóg.

Postawa dziękczynna w Éomencie modlitwy błagalnej ma swoje uzasadnienie we względności czasu. Bóg istnieje w sposób ponadczasowy. Do takiego bytowania powołany jest równiez człowiek. Gnostyk dzięki ścisłej więzi z Bogiem już tu na ziemi, wznosi się w pewnym stopniu na poziom egzystencji ponadczasowej, co pozwala mu przezywać jednocześnie wydarzenia przeszłe, teraźniejsze i przyszłe ${ }^{10}$.

"Gnostyk potrafi się cieszyć z obecnych dóbr, potrafi
sie cieszyć nawet z tych, które mu na razie zostały
tylko obiecane, tak jakby juz stały się rzeczywiste.
Nie sazprzed nim ukryte jeszcze nieobecne, gdyż juz
przedtem je poznał, jakie one sa. Przekonany przez
swa władzę poznawczą, że to, co ma być juź jest, już
obecnie posiada to dobro /... / w ten sposób gnostyk
posiada wsystkie dobra w stanie potencjalnym, ale
jeszcze nie w wymierzonej liczbowo rzeczywistosci"11.

Przy takim podejściu do wartości czy to duchowych, czy materialnych postawa wdzięczności jest w pełni uzasadniona i logiczna. Będąc przyjacielem Boga i uczestnicząc dzięki gnozie w Jego bogactwie gnostyk posiada wartość najwyższa, co w pełni go satysfakcjonuje i stanowi motyw dziękezynienia.

Pozostając w tak ścisłej jedności z Bogiem gnostyk staje się współwłaścicielem tego, co jest własnością Boga. Nie potrzebuje on ubiegać się o posiadanie czegokolwiek jakoby "na własną rękę", gdyż

10 F. Drączkowski, Kościół-agape, dz.cyt., 115: "Dzięki a g a p e gnostyk niejako partycypuje w bycie życia Bożego, czyli jakby przebywa w niebie /.../ Za pośrednictwem miłości przyszłe jest dla niego już teraźniejszością".

11 Stromateis VII $47,4-7, \operatorname{GCS} 17,35$. 
poprawność moralna. Jest to warunek niewątpliwie najważniejszy, gdy chodzi o obcowanie z Bogiem czy wysłuchanie modlitwy, jednakże w tym miejscu nie będziemy go szczegółowo omawiać, glyż w przypadku gnostyka jest to rzecz oczywista ${ }^{19}$. Gnostyk bowiem już we wstępnym etapie procesu udoskonalania się zerwał $z$ grzechem i trwa w stanie czystości. Ona jest istotnym warunkiem do nawiązania kontaktu z Bogiem 1 trwania z Nim w łączności 20 .

Klemens często podkreślał wyższość gnostyka nad tzw. zwykłymi chrześcijanani i uważał za rzecz oczywistą, że nodlitwa gnostyka jest miła Bogu, a przedstawiane przezeń prośby bywają wysłuchiwane:

\footnotetext{
"Dlatego przysto1 modítwa tym przede wszystkim, którzy poznali to, co Boskie i w sposób właściwy posiadają cnotę Bogu ołpowiadającą; którzy wiedzą, co jest dobrem prawdziwym, o co należy prosić i jak prosić w poszczególnym wypadku"21.
}

Posiadanie cnoty odpowiadającej Bogu, świadomość tego co dobre, zgodność własnej woli z wolą Bożą, a w zwiézzku z tym skierowanie odpowiedniej prośby do Boga, sprawiaja, że prośba taka jako zgodna z zamiaren Bożyn, bywa przyjęta $i$ wysłuchana.

Chcąc następnie podkreślić znaczenie świętości osobistej oraz jej związek z modlitwą dotyka klemens problemu modlitwy ludzi, którzy nie wznieśli się na poziom gnozy. Mówiąc o tej grupie ma on na myśli zarówno zwykłych chrześcijan, którzy nie osiagnnęli jeszcze doskonałej agape, lecz sa niejakow drodze do niej, jak i tych, którzy są zbyt leniwi, by podejmować jakikolwiek wysiłek ascetyczny. Modlitwie tych pierwszych równieź przyznaje pewne wartości, lecz zagadnienie to traktuje zupełnie marginesowo; zdecydowanie natomiast odrzuca modły grzeszników:

"Dla ludzi złych modiitwa nie tylko w stosunku do innych, ale $i$ do nich samych jest w najwyżsym stopniu szkodliwa. Jeśli nawet dzięki swej prośbie otrzymają to, co uważaj za pomýślne, to właśnie uzyskane pozor-

19 Por. W. Vylker, Der wahre Gnostiker nach Clemens Alexandrinus, Berlin 1952, 541-546.

20 Por. Mt 5, 8: "Bło josławieni czystego serca, albowien oni Boga ogliz̨lać będą".

21 Stromateis VII 39,1, GCS 17,30 . 
ne dobro wyjdzie im na niekorzyść, ponieważ nie wiedzą, Jak je wykorzystać w sposób właściwy. Modlą się bowiem o uzyskanie tego, czego nie mają i domagają się tych dóbr, które uwaźają za dobre, a nie tycin, które są nimi istotnie"22.

Pogląd ten łatwo jest zrozumieć w świetle ogólnych założé Klemensa, który był zwolennikiem swoistego intelektual,izmu i elitaryzmu religijnego ${ }^{23}$. Chrześcijaninem w pełnym tego słowa znaczeniu był dla niego tylko człowiek posiadający odpowiednią wiedzę, zarówno świeckiz, Jak i teologiczno-filozoficzną, oraz reprezentujący wysoki poziom moralny. Ludzie wewnętrznie niezintegrowani nie są w stanie poznać Boga, nie rozumieją Jego planów ani tajemnic, a w związku z tym nawet gdy wierzą w Jego istnienie, żyją z dala od Niego. Nie tworzą z Nim bowlem wspólnoty życia:

\footnotetext{
"Wszystko, co ślepe i głuche, nie mające świadomości ani nieustraszonego $i$ przenikliwego wzroku duszy lubującej się w kontemplacji wzroku, którego sam Pan użycza /.../ wszystko, co jeszcze nie oczyszczone lub nie znające świętej Prawdy /.../ lgnące do materii, winno pozostać poza boskim chórem"24.
}

Ci zatem, którzy "pozostają poza boskim chórem", nie są w stanie poznać, co dla nich jest pożyteczne, a jeżell nawet otrzymują pewne dary od Boga, to nie zamsze zdają sobie z tego sprawę 1 nie wiedzą, jak je wykorzystać. Nawet gdyby nie nadużyli tego, co posiadają, to nie pomaga im to do budowania wspólnoty z Bogiem.

Nie tylko jednak modlitwa ludzi złych pozostaje według Klemensa bezowocna, ponieważ również ci, którzy powstrzymują się od ciężkich grzechów, ale nie postępują na drodze cnoty, nie potrafią obcować z Bogiem. Ich prośby bowiem także nie przynoszą skutków:

"Jest oczywiste, że ci wszyscy, którzy nie pełnią dobrych czynów, tym samym nie wiedzą, co jest dla

22 Stromateis VII 44,1 , GCS $17,33$.

23 Por. G. Lazzat1, Introduzione allo studio di Clemente Alessandrino, Milano 1939, 60-71.

24 Stromateis V 19, 2, GCS $52,338$. 
nich pożyteczne. A jeśli tak jest, to w takim razie nie są oni również w stanie modlić się należcie o otrzymanie od Boga tego, co jest dobre, gdyż nie wiedza, co rzeczywiście jest dobre. A nawet gdy otrzymaja jakieś dobro, to nie są zdolni dostrzec tego daru"25.

Przecirieństwem takich ludzi saz gnostycy, zatopieni w Bogu oraz dostrzegający wszędzie Jego obecność 1 działanie. Nic zatem dziwnego, że między przyjaciółmi Boga czyli gnostykami, a nowo nawróconymi istnieje, zdaniem Klemensa, różnica, gdy chodzi o sam sposób otrzymywania darów:

\footnotetext{
"Tym ludziom, którzy nawrócili się z grzechów, ale nie osiągnęli jeszcze trwałej wiary, użycza Bóg spełnienia życzeń dopiero na ich usilne błagania, tym zaś, którzy żyją w sposó bezgrzeszny i gnostyczny, daje Bóg, gdy tylko pomyślą"26.
}

Gnostycy pozostający w łączności z Boglem myślą kategoriami nadprzyrodzonymi. Ich pragnienia i myśli wyrazane w modlitwach pokrywają się z zamiarami Bożymi. Z tego też względu Bóg realizując 1ch pragnienia wypełnia swój odwieczny plan zbawczy, a gnostyk jest aktywnym uczestnikien dzieła zbawienia. "Funkcję zbawczą pełni każdy, kto upodabnia sie do Zbawiciela w tym stopniu, w jakim tylko jest możliwe dla ludzkiej natury wymodelowanie obrazu Boga w sobie, wypełniając w sposób nieprzekraczalny to wszystko, co wynika z Boskich przykazań, to znaczy potrafi czcić Bóstwo przez prawdziwa sprawiedliwość: przez czyny i poznanie. Nie odwleka Pan wysłuchania jego głosu w modlitwie mówiąc: "żądaj, a uczynię, pomyśl, a dam" 27 .

Tak więc tajemnica natychmiastowego wysłuchania modlitwy błagalnej gnostyka tkwi zarówno w jego miłości do Boga 1 świętości osobistej, jak 1 w tym, że gnostyk uczestniczy aktywnie w dziele zbawienia. Wszystkie jego pragnienia 1 modlitwy, nawet te, których przedmiotem byłyby sprawy doczesne, nie zmierzają do narzucenta

25 Stromateis VI 112, 4, GCS 52, 488.

26 Stromateis VI 101,3, GCS $52,482$.

27 Strnmateis VI $77,5-78,1$, GCS 52,470 ; por. Mt. 7,7 . 
Bogu własnej woli, lecz mają na celu realizacje Jego planów. Wszystkie prośby, Jakie gnostyk kieruje do Boga prowadzą do tego samego celu. Chociaż gnostyk posiada wszystko w Bogu, jednakże ciaggle powinien zanosić modlitwy błagalne, aby mógł się stawać coraz aktywniejszym współpracownikiem Boga w dziele zbawienia. W tym znaczeniu prośba jest obowiązkiem gnostyka ${ }^{28}$, gdyż bez Bożej pomocy nie byłby on w stanie wypełnic tak wzniosłych zadań. Podstawa zaś wszystkiego jest czystość serca warunkująca permanentny rozwój agape rozumianej jako wspólnota źycia z Bogiem.

Ks. Józef Grzywaczewski - Siedlce

DE QUAESTIUNE ORATIONIS EXAUDIENDAE APUD CLEMENTEM ALEXANDRINT /Argumentum/

Clemens Alexandrinus perfectum christianum gnosticum appellat. Gnosticus autem, qui homo mundo corde habetur, Deum et omnia in Deo amat. Adeo enim voluntaten $\mathrm{De}_{\mathrm{i}}$ cognovit, ut eiusdem amicus ac cooperator in mundo salvando dici posset. Gnosticus solummodo pro eis orat, quae Deus vult. Deus autem orationem gnostici accipiens propriam voluntatem facit. Hoc modo oratio gnostici semper exauditur.

28 Stromateis VII 41, 6, GCS $17,31$. 